Український мовно-інформаційний фонд НАН України. 2018. 271 с. DOI 10.33190/978-966-02-8683-2/8684-9.

3. Академічна культура дослідника в освітньому просторі: європейський та національний досвід [Текст] : збірник матеріалів II Міжнародної науково-практичної конференції, (м. Суми, 16-17 травня 2019 року) / за ред. О. М. Семеног. - Суми : Видавництво СумДПУ імені А. С. Макаренка, 2019. - 220 с.

DOI https://doi.org/10.30525/978-9934-26-073-5-1-15

\title{
РОМАН Т. ТОЛСТОЙ «КЫСЬ» В СВЕТЕ ЯЗЫКОВОЙ ИГРЫ
}

\section{Сербина Т. Г.}

кандидат филологических наук, доиент, доиент кафедры теории и истории мировой литературы Ривненского государственного гуманитарного университета 2. Ровно, Украина

\section{Чеберяк А. Н.}

кандидат филологических наук, доцент, дочент кафедры романно-германской филологии Ривненского государственного гуманитарного университета г. Ровно, Украина

Ведущими принципами языкового построения постмодернистского текста провозглашаются деструктивизм, абсурдизм и развенчание стереотипов. Формальным приемом реализации этих принципов становится языковая игра (ЯИ).

Большинство исследователей $[1,2,3]$ видят в ЯИ намеренное речетворчество автора, основанное на отступлении от любой языковой нормы «для создания остроумных высказываний, в том числе комического характера» $[4$, с.79]. Иллюстрацией умелого использования языковой игры в художественном тексте служит роман «Кысь» Татьяны Толстой.

Толстая называет свой роман лингвистической утопией, что проявляется в экзотичности ее языка. В романе придумана флора и фауна, множество реалий, для названия которых она использовала окказиональное словообразование. В частности, растут там ржавь и хлебеда, хвощ и огнецы, в лесу живут кысь, слеповран и древяница, едят 66 
червырей, козляков и грибыши и т.Д. В игре со словом активно используются необычные для этих лексем суффиксы: червыри, козляк, грибыши, огнецы, чужанин, тряпица, хребтина, не жалобьтесь, пужалище, колоть $(\mathbf{j})$ e, курь (j)ё, ложица, вилица, буквица, кудерьки. Некоторые из окказионализмов образованы при помощи контаминации или основосложения и суффиксации: хлебеда (хлеб+лебеда), пупырь (пуп+волдырь), клель (клен+ель); срамословие (срам+слово), неудобосказуемый (неудобный+сказать), страховидное (страх+вид) и др. Особенно экспрессивны семантически невнятные для читателя словаокказионализмы, мотивирующую основу которых невозможно установить: гонобобель, ржавь, кыссь, курдалясинь, боботюкалки, кукумаколки, разлюлюшки, колобашки, михрютка, фордыбачить, mулумбасы, подъелдыкивать и др. Указанные лексемы создают особую коннотацию сказочности и экзотичности повествования, что соответствует замыслу и жанру произведения Т.Толстой.

Языковая игра проявляется и в переосмыслении ряда слов, используемых для обозначения придуманных Толстой антиутопических реалий. По сюжету после Взрыва (именно с прописной буквы) у многих оставшихся в живых проявляются «последствия» (всевозможные мутации), простых граждан здесь называют «голубчиками» (аллюзия на слово «товарищ»), соседей (чужих) - «чеченцами», деньги - «блящками». Среди населения живут «прежние» - это те, кто выжил после взрыва (намек на дореволюционную интеллигенцию), кроме них есть «nерерожденцыь» - их используют в качестве лошадей (намек на «Архипелаг Гулаг» А. Солженицина, где он описывает, как заключенные вместо лошадей тащили повозки с бревнами). Словом «Болезнь» называется своеволие, доступ к старопечатным книгам, а «лечением» уничтожение, казнь за своеволие и ослушание. Голубчики «перебеляют» (переписывают) книги, будто бы написанные Наибольшим Мурзой Федором Кузьмичем (главным правителем города). В Складской день (день зарплаты) получают со Склада продукты и необходимые в хозяйстве вещи. Все эти слова являются семантическими окказионализмами.

Графически выделены слова из прежней жизни, причем игровой эффект достигается двумя способами - написанием всего слова прописными буквами и использованием приема «фонетической ослышки»: МОГОЗИН, ФЕЛОСОФИЯ, ОНЕВЕРСТЕЦКОЕ АБРАЗОВАНИЕ, ОСФАЛЬТ, ЭНТЕЛЕГЕНЦЫЯ, ТРОДИЦЫЯ, ШАДЕВРЫ. Такие слова употребляют исключительно Прежние, а главный герой повторяет их в 
искаженном виде, не понимая смысла, поскольку в придуманном Толстой мире не существует таких реалий.

С точки зрения фонетической одним из приемов ЯИ в повествовании является стилизация под говор малообразованных людей. Толстая употребляет просторечные формы слов, ставшие результатом диссимиляции, метатезы и субституции: секлетарь, обчественные процессы, обчество, диалехтика, проконпастируют, каклеты, канпот, писдолет,тубарет,пинзин,нетути, по-еёному, цельная книга, незнам что, тульпан, сужет. Использует Т. Толстая и рифмованное эхо: пушкинколотушкин, птица-блядуница, курь-о-курь летят, девка-припевка.

Морфологические преобразования включают в себя изменение форм рода, падежа, неправильное образование форм склонения и спряжения, устаревшие формы глагола: шарлот (шарлотка), буратина (буратино), свеклец (свекла); ходют (ходят), печалуются (печалятся), помре (умерла), попрятамшись (попрятались), не разжамши (не разжав), лицезреть (уст. видеть).

На лексическом уровне в качестве ЯИ автор использует омонимическое сближение слов, столкновение прямого и переносного значений в одном ряду для создания комического эффекта:

- Отчего бы это, сказал Никита Иванович, - отчего это у нас все мутирует, ну все! Ладно люди, но язык, понятия, смысл! А? Россия! Все вывернуто! - Не все, - поспорил Бенедикт. - Вот разве если сыру съешь, то да, внутрях мутирует и выворачивает. А если пирожок, то ничего... Никита Иванович!.. [5, с. 229].

В исследуемом тексте частотны литературные аллюзии: - Я слыхал, осторожно сказал Бенедикт, что это традиция. - Какая традиция? - А лечить. Что раньше от книг радиация была, вот и лечили, у кого книга. А теперь двести лет прошло, так это уж все равно. Такая традиция. - (...) Стало быть, так... Не в книгах Болезнь, мил человек, а в головах! [5, с. 186]. Намек на слова проф. Преображенского в «Собачьем сердце» М. Булгакова «Следовательно, разруха не в клозетах, а в головах!»

Постмодернистская игра Толстой - это деконструкция, отказ от классической традиции. Благодаря игре со словом Толстая создала яркий антиутопический язык (новояз), который отразил мутировавшую национальную самобытность описываемого общества.

\section{Литература:}

1. Гридина Т.А. Языковая игра в художественном тексте. Екатеринбург, 2008. 165 с. 
2. Игра как прием текстопорождения: коллективная монография / под ред. А.П. Сковородникова. Красноярск, 2010.341 с.

3. Радбиль Т.Б. Языковая аномалия как норма художественного дискурса. Филологические науки. 2006. № 6. С. 50-58.

4. Сковородников А.П. О понятии и термине «языковая игра». Филологические науки. 2004. № 2. С. 79-87.

5. Толстая Т.Н. Кысь. Москва, 2003. 320 с.

DOI https://doi.org/10.30525/978-9934-26-073-5-1-16

\title{
МОВНА ОСВІТА У ДИСТАНЦИЙНОМУ ФОРМАТІ
}

\author{
Томенко О. М. \\ кандидат філологічних наук,
}

дочент кафедри культури та соиіально-гуманітарних дисииплін

Національної академії образотворчого мистецтва і архітектури

м. Київ, Украӥна

Особливість вивчення української мови за професійним спілкуванням у художньому навчальному закладі полягає у різних засобах досягнення мовної та мовленнєвої компетентності. Насамперед - це володіння основами культури усного та писемного мовлення, а також практичні навички використовувати мовні знання в усіх сферах спілкування, особливо під час дистанційного навчання та у професійній діяльності. Сучасний комунікативний світ ставить такі вимоги до студентів художнього навчального закладу, які зобов'язують його чітко та логічно сформулювати та донести думку, щоб отримати бажаний результат у навчальній, культурній чи науковій царині.

У сфері мистецької освіти це особливо важливо, адже творча робота не може бути замкнена лише простором майстерні чи аудиторії. Результат будь-якої творчої діяльності повинен бути донесений до загалу. I від того, наскільки грамотними, переконливими та логічними будуть судження, висловлені в процесі дистанційної комунікації, залежить результат навчання, оцінювання, професійного зростання, успішної майбутньої професійної діяльності. Адже живе та віртуальне (дистанційне) спілкування має кардинальні відміності.

Мовна освіта у мистецькому закладі - одна із суттєвих складових при здобуті фахової освіти. Мовна компетентність $є$ одним із засобів для здобуття повноцінної фахової освіти. Сучасна художня освіта, зокрема 